\title{
Sensor Based on PZT Ceramic Resonator with Lateral Electric Field for Immunodetectionof Bacteria in the Conducting Aquatic Environment ${ }^{\dagger}$
}

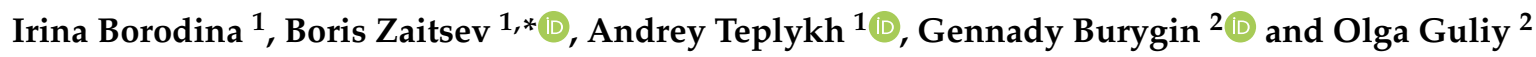 \\ 1 Kotelnikov Institute of Radio Engineering and Electronics of RAS, Saratov Branch, 410019 Saratov, Russia; \\ borodinaia@yandex.ru (I.B.); teplykhaa@mail.ru (A.T.) \\ 2 Institute of Biochemistry and Physiology of Plants and Microorganisms, Russian Academy of Sciences, \\ 410049 Saratov, Russia; burygingl@gmail.com (G.B.); guliy_olga@mail.ru (O.G.) \\ * Correspondence: zai-boris@yandex.ru; Tel.: +7-8452-272401 \\ + This paper is an extended version of the paper entitled "Acoustic sensor for detection and identification of \\ microbial cells directly in the liquid phase" presented at 2019 IEEE International Ultrasonic Symposium \\ (IUS), Glasgow, UK, 6-9 October 2019.
}

Received: 26 April 2020; Accepted: 22 May 2020; Published: 25 May 2020

\begin{abstract}
A biological sensor for detection and identification of bacterial cells, including a resonator with a lateral electric field based on PZT ceramics was experimentally investigated. For bacterial immunodetection the frequency dependencies of the electric impedance of the sensor with a suspension of microbial cells were measured before and after adding the specific antibodies. It was found that the addition of specific antibodies to a suspension of microbial cells led to a significant change in these frequency dependencies due to the increase in the conductivity of suspension. The analysis of microbial cells was carried out in aqueous solutions with a conductivity of $4.5-1000 \mu \mathrm{S} / \mathrm{cm}$, as well as in the tap and drinking water. The detection limit of microbial cells was found to be $10^{3}$ cells $/ \mathrm{mL}$ and the analysis time did not exceed $4 \mathrm{~min}$. Experiments with non-specific antibodies were also carried out and it was shown that their addition to the cell suspension did not lead to a change in the analytical signal of the sensor. This confirms the ability to not only detect, but also identify bacterial cells in suspensions.
\end{abstract}

Keywords: immunodetection of microbial cells in aqueous medium; PZT resonator with lateral electric field; electrical impedance; antibodies (Abs)

\section{Introduction}

The development of new biosensor systems for the detection and identification of microbial cells in aquatic environments is an urgent problem in modern microbiology. It is important to consider the possibility of analysis in conditions of increased conductivity of the measurement medium, since the high conductivity of the medium significantly complicates the process of detection and identification of bacteria. Most existing biosensors for detecting bacteria are poorly adapted for measurements in water used in industry, municipal, and commercial institutions, the electrical conductivity of which is high due to the presence of various ionic compounds [1-6].

Therefore, new methods are being actively developed for the analysis of microorganisms in conductive liquids, which are distinguished by the high sensitivity, accuracy, and speed. In this regard, the electro-acoustic analysis methods are promising [7-9]. For the detection and identification of microbial cells, biosensors based on a resonator with a lateral electric field are widely used [10-18]. Nevertheless, the problem of increasing the sensitivity of such sensors remains relevant. 
Researchers have also paid attention to finding the promising new materials for acoustic biosensors. Traditionally, such materials as lithium tantalate, lithium niobate, and quartz have been widely used to develop sensors based on resonators with a lateral electric field [16-18]. However, the use of PZT piezoceramics for the development of acoustic sensor technology is also promising [19]. This material is characterized by a high coefficient of electromechanical coupling [20], i.e., the corresponding sensors will be more sensitive to changes in the conductivity of the contacting liquid. An additional advantage of piezoceramics is low cost, which opens up great opportunities for the mass production of sensors.

The possibility of using a sensor based on a resonator with a lateral electric field made of PZT ceramics for the express analysis of microbial cells in aqueous solutions with a conductivity of $4.5-1000 \mu \mathrm{S} / \mathrm{cm}$, as well as in the tap and drinking water, was investigated.

\section{Materials and Methods}

\subsection{The Microbial Cells and Reagents}

Azospirillum brasilense strain Sp7 (IBPPM 150) and Escherichia coli strain K-12 (IBPPM 204) were taken from the IBPPM RAS Collection of Rhizosphere Microorganisms (http://collection.ibppm.ru/). Microbial cells were grown in Luria-Bertani's liquid medium and prepared for measurement as described in [14]. Before analysis, the bacterial cells were thoroughly washed in distilled water by the centrifugation (three times, at $2800 \times g, 5 \mathrm{~min}$ each) and were re-suspended in distilled water (conductivity, $4.5 \mu \mathrm{S} / \mathrm{cm}$ ). The absorbance of the prepared suspension was brought to $D_{600}=0.4-0.42$. Then $1 / 10,1 / 100,1 / 1000$, etc., dilutions (1 part of cell solution, 9 parts of buffer solution), were used.

The antibodies (Abs) specific to the lipopolysaccharide of A. brasilense Sp7 were grown as described in [21]. The strain-specificity of the antibodies was studied by the double immunodiffusion in the $1 \%$ agarose gel by using the standard technique [22].

\subsection{Enzyme-Linked Immunosorbent Assay (ELISA)}

Detection of interactions of antibodies with bacterial cells was carried out by ELISA in 96-well polystyrene plates using the standard procedure, as previously described in [23]. Aliquots ( $50 \mu \mathrm{L})$ of each bacterial suspension in twofold dilutions (initial concentration, $10^{8}$ cells $/ \mathrm{mL}$ ) were immobilized in the wells through simple adsorption, and kept for $30 \mathrm{~min}$ on a shaker at room temperature. The samples were replaced with $100 \mu \mathrm{L}$ of $0.05 \%$ polyethylene glycol 20,000 (PEG), added to each well to block the free binding sites on polystyrene. This solution was replaced by $50 \mu \mathrm{L}$ of Abs specific to the lipopolysaccharide of A. brasilense Sp7 (final conc. $0.2 \mathrm{mg} / \mathrm{mL}$ ) diluted in phosphate-buffered saline (PBS) with $0.02 \%$ Tween 20 and $0.005 \%$ PEG (for prevention of nonspecific Ab sorption). After incubation for $30 \mathrm{~min}$, the wells were washed three times with $100 \mu \mathrm{L}$ of PBS- $0.02 \%$ Tween 20 . Horseradish peroxidase conjugated with goat anti-rabbit antibodies (Jackson ImmunnoResearch Laboratories, West Grove, PA, USA; diluted 1:2000) was used as an enzyme label. Peroxidase activity was estimated by adding to each well $50 \mu \mathrm{L}$ of a substrate mixture of $0.03 \%$ o-phenylenediamine and $0.02 \%$ hydrogen peroxide in $0.1 \mathrm{M}$ sodium citrate buffer (pH 4.5). The enzyme reaction was stopped with $100 \mu \mathrm{L}$ of $1 \mathrm{~N}$ $\mathrm{H}_{2} \mathrm{SO}_{4}$. The absorbance at $492 \mathrm{~nm}$ was read on a Multiskan Ascent analyzer (Thermo, Vantaa, Finland). Absorbance values at $492 \mathrm{~nm}$ for the wells without bacterial cells were used as the control. Data were processed with Microsoft Excel 2003 software (Microsoft Corp., Redmond, USA); 95\% confidence intervals are given.

\subsection{Electron Microscopy}

The samples for electron microscopy were prepared as described in [24] and were viewed by a Libra 120 transmission electron microscope (Carl Zeiss, Oberkochen, Germany) at an accelerating voltage of $120 \mathrm{kV}$. The microscopy of the samples was done at the Simbioz Center of the IBPPM RAS. 


\subsection{Measuring Medium}

The analysis of microbial cells was carried out directly in the liquid phase. We used distilled water (the conductivity $=4.5 \mu \mathrm{S} / \mathrm{cm}$ ) and standard $0.12 \mathrm{M}$ phosphate-buffered saline (PBS) (pH 7.2) of the following composition (g/L): $\mathrm{KH}_{2} \mathrm{PO}_{4}, 0.43 ; \mathrm{Na}_{2} \mathrm{HPO}_{4}, 1.68 ; \mathrm{NaCl}, 7.2$ (the conductivity = 10, 20, 50, $100,300,500$, and $1000 \mu \mathrm{S} / \mathrm{cm}$ ). The conductivity of the buffer was changed by adding distilled water and was determined with a HANNA HI 8733 (Ecoinstruments, Moscow, Russia). The viscosity of the buffer solutions with microbial cells was measured using a viscometer SV-10 (A\&D Company, Limited, Tokyo, Japan).

\subsection{Description of Sensor and Method of Experiment}

The general scheme of the experiment is presented in Figure 1. We used a sensor based on the resonator with a lateral electric field made of PZT ceramics. Two aluminum electrodes were deposited on one side of the resonator. The other side was the bottom of the liquid container. The characteristics of this sensor are described in more detail in [25].

For research, the resonator was connected to the impedance analyzer E4990A (Keysight Technologies, Santa Rosa, CA, USA), and the frequency dependences of the real and imaginary parts of the electrical impedance were measured in the frequency range 50-300 kHz. First, the characteristics of a sensor with a container filled with distilled water or a buffer solution with a given conductivity were studied. At the next stage, distilled water or a buffer solution with microbial cells was placed in the container and the sensor readings were again recorded. After this, the specific or nonspecific antibodies (Abs) were added to the container with a cell suspension, and the parameters of the sensor were measured. Measurements were carried out for different cell number $\left(10^{2}-10^{8} \mathrm{cells} / \mathrm{mL}\right)$, as well as for different antibodies concentration $(1-6 \mu \mathrm{g} / \mathrm{mL})$ added to the cell suspension. The conductivity of distilled water was equal to $4.5 \mu \mathrm{S} / \mathrm{cm}$, the conductivity of buffer solutions varied from 10 to $1000 \mu \mathrm{S} / \mathrm{cm}$.

As an analytical signal, we used the change in the maximum value of the real part of the electric impedance of the sensor after adding the specific antibodies to the suspension of bacterial cells.

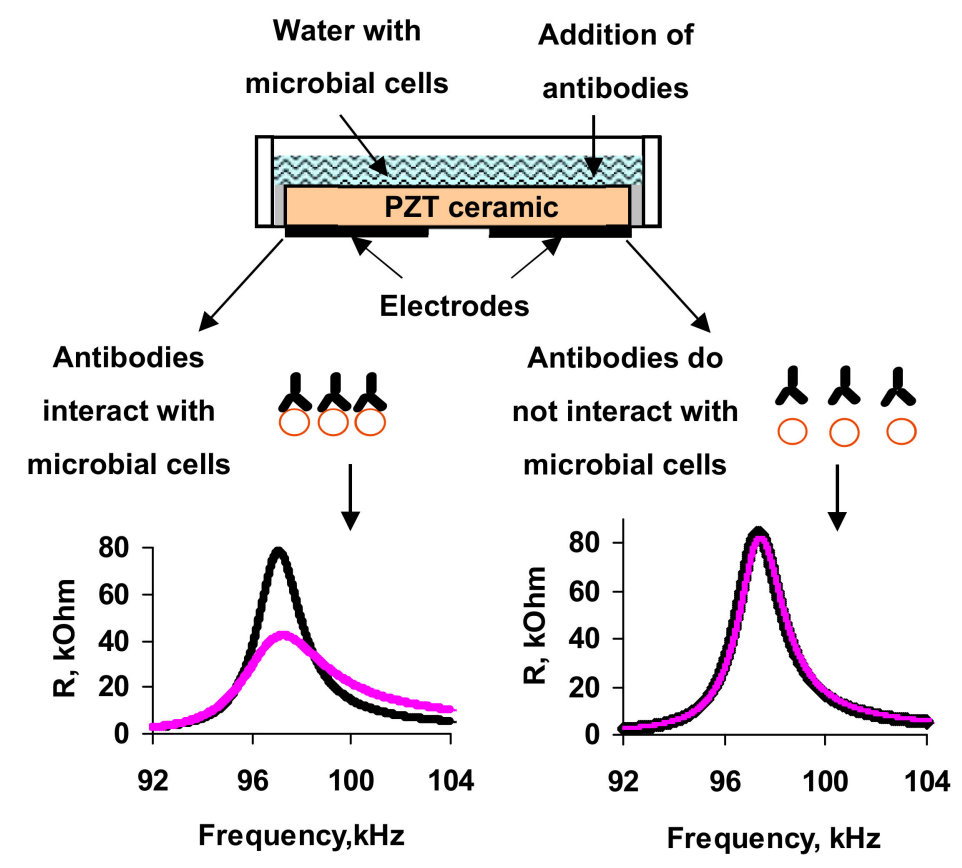

Figure 1. The general scheme of the experiment. 


\section{Results and Discussion}

\subsection{Measurements in Distilled Water}

Measurements of the parameters of the sensor with an empty container showed the presence of three resonances in the frequency dependences of the real (R) (Figure 2a) and imaginary (X) (Figure 2b) parts of the electrical impedance of the resonator. These resonant peaks were observed near the frequencies of $68.7,97.8$, and $264 \mathrm{kHz}$, and had the values of electromechanical coupling coefficient of $15 \%, 14 \%$, and $5 \%$, respectively [25].

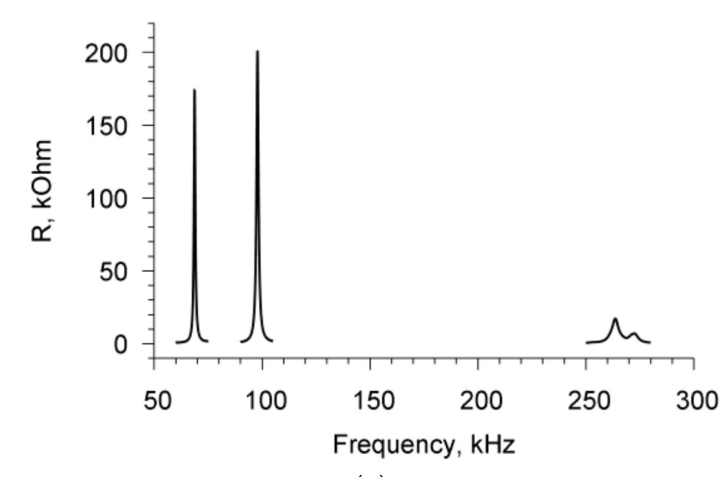

(a)

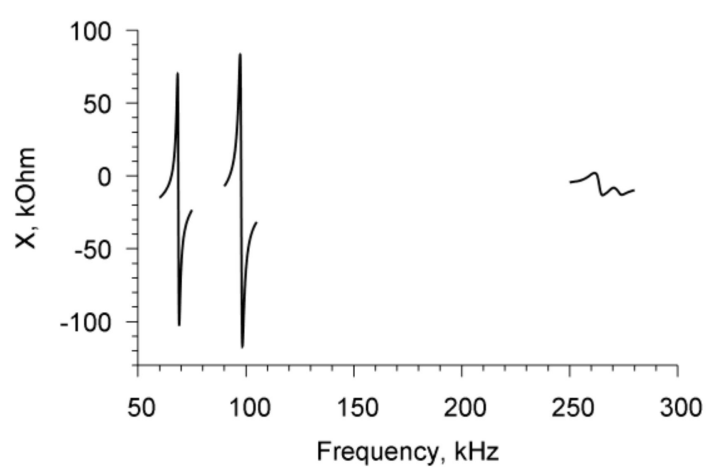

(b)

Figure 2. The frequency dependencies of the real (a) and imaginary (b) parts of the electrical impedance of PZT resonator with empty liquid container.

In the next step, distilled water was added to the container. The addition of distilled water with a conductivity of $4.5 \mu \mathrm{S} / \mathrm{cm}$ led to the significant decrease in the maximum value of the real part of the electrical impedance $\left(R_{\max }\right)$ for all resonant peaks in comparison with an empty container. This is apparently due to the fact that, firstly, the liquid layer exerted a massive load on the resonator. Secondly, the acoustic oscillations excited in this resonator were not purely shear, but had a small normal displacement component, which led to small radiation attenuation.

It was found that the quality factor of each resonance in contact with the liquid turned out to be significantly higher than one of a resonator with a longitudinal acoustic wave based on lithium niobate [13-15]. This is due to the fact that in a piezoceramic resonator the shear component of the mechanical displacement is prevalent, which significantly reduces the radiation loss of the acoustic wave when the surface of the resonator contacts the liquid [25].

Then, microbial cells, re-suspended in distilled water with a given concentration $\left(10^{2}-10^{8} \mathrm{cell} / \mathrm{mL}\right)$, were added to the container. It was shown that the addition of distilled water with microbial cells in container had practically no effect on the frequency dependences of the electrical impedance of resonator in comparison with adding the water without cells.

The surface of a microbe cell is a set of complicated antigen complexes. The distinctive feature of antibodies to form specific compounds with the appropriate antigens is used for determination of microorganisms. The same principle is employed to identify the microorganisms with the help of biosensor systems by using the Abs. Therefore, as a selective agent for determining bacteria, we used antibodies specific to them.

In the next measurement step the specific Abs were introduced into the cell suspension of A. brasilense Sp7. Different amounts of microbial cells $\left(10^{2}, 10^{3}, 10^{4}, 10^{6}\right.$ and $10^{8}$, cells $\left./ \mathrm{mL}\right)$ and specific Abs $(1,2,4$, and $6 \mu \mathrm{g} / \mathrm{mL})$ were used in the experiments. The addition of specific Abs to A. brasilense $S p 7$ led to a significant decrease in the real and imaginary parts of the electrical impedance of the resonator for almost all values of the studied cell concentrations excepting $10^{2}$ cells $/ \mathrm{mL}$. 
As already noted, as an informative parameter, we used the maximum value of the real part of the electric impedance of the resonator because it was shown earlier that this parameter is preferable for measuring the conductivity and viscosity of a liquid [17].

Figure 3 presents, as an example, the frequency dependencies of the real part of the electric impedance of the sensor for cell suspension of A. brasilense Sp7 with concentration of $10^{3}$ cells $/ \mathrm{mL}$ before (curve 1) and after (curve 2) adding the specific Abs with the amount of $4 \mu \mathrm{g} / \mathrm{mL}$. The dependencies are presented for three resonance peaks near the frequencies: (a) $68.7 \mathrm{kHz}$, (b) $97.8 \mathrm{kHz}$, and (c) $264 \mathrm{kHz}$.

One can see that the addition of specific Abs to the suspension of microbial cells leads to a decrease in the maximum value of the real part of the electrical impedance $\left(R_{\max }\right)$ by $63.5,65.6$, and $4.1 \mathrm{kOhm}$ for resonance peaks near frequencies of $68.7,97.8$, and $264 \mathrm{kHz}$, respectively.

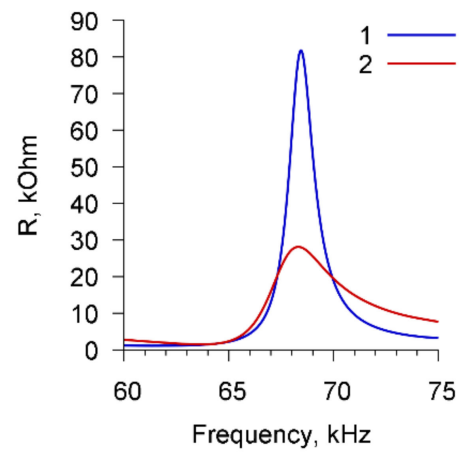

(a)

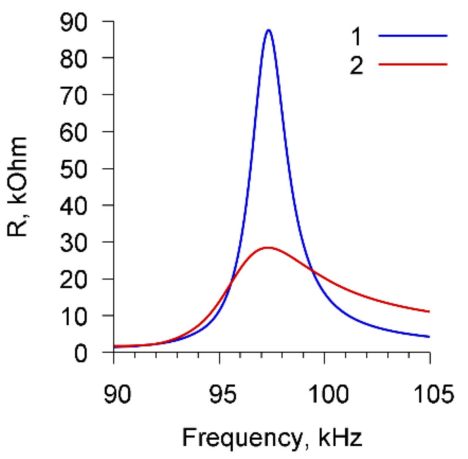

(b)

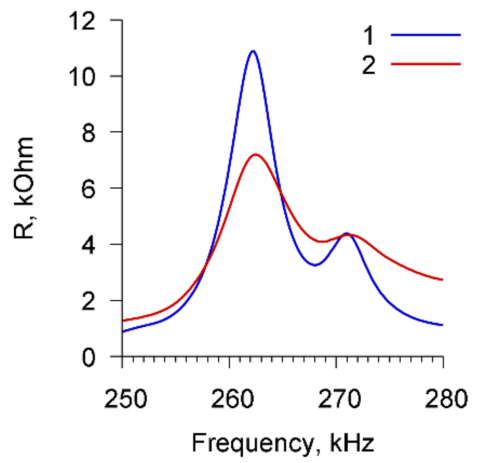

(c)

Figure 3. The frequency dependencies of the real part of the electrical impedance of PZT resonator with container loaded by A. brasilense Sp7 suspension before (curve 1) and after (curve 2) adding the specific Abs. The cell concentration was $10^{3}$ cells $/ \mathrm{mL}$, the concentration of Abs was $4 \mu \mathrm{g} / \mathrm{mL}$. (a) Peak near $68.7 \mathrm{kHz}$, (b) peak near $97.8 \mathrm{kHz}$, (c) peak near $264 \mathrm{kHz}$.

The changes in the parameters of the sensor can be explained as follows. When specific antibodies are added to the cell suspension, the active center of the antibody $(\mathrm{Ab})$ joins with the antigenic $(\mathrm{Ag})$ determinant. This highly specific process proceeds in aqueous solutions at a high speed. O-antigen of the Gram-negative bacteria is associated with lipopolysaccharide LPS of the cell wall. The determinant groups of this complex antigen are the terminal repeating units of polysaccharide chains attached to its main part. At the moment of binding the antibody to the determinant group of the antigen, a conformational rearrangement of the active center of the antibody occurs and the active antibody adapts to the antigen. The binding of antibodies to antigenic determinants on the cell surface is recorded by changing the polarization properties of the Ag-Ab complex. The interaction of an antigen molecule with an antibody or its active Fab fragment is accompanied, in turn, by changes in the spatial structure of the antigen molecule. This affects the change in the integrity of bacterial membranes, and leads to the release of cell contents into suspension and to the increase in its electrical conductivity. This increase in conductivity is recorded by the acoustic sensor as a decrease in the real and imaginary parts of the electrical impedance of the resonator near the resonant frequencies.

To exclude the nonspecific interactions, we used E. coli K-12 cells and Abs specific for A. brasilense $\mathrm{Sp7}$ cells. Figure 4 shows, as an example, the frequency dependencies of the real part of the electric impedance of the sensor for a suspension of $E$. coli K-12 cells $\left(10^{3}\right.$ cells $/ \mathrm{mL}$ ) before (curve 1$)$ and after (curve 2) the addition of Abs specific for A. brasilense Sp7 $(4 \mu \mathrm{g} / \mathrm{mL}$ ). These dependencies are presented for three resonance peaks near frequencies: (a) $68.7 \mathrm{kHz}$, (b) $97.8 \mathrm{kHz}$, and (c) $264 \mathrm{kHz}$. It can be seen that in this case no changes in the sensor parameters are observed. 


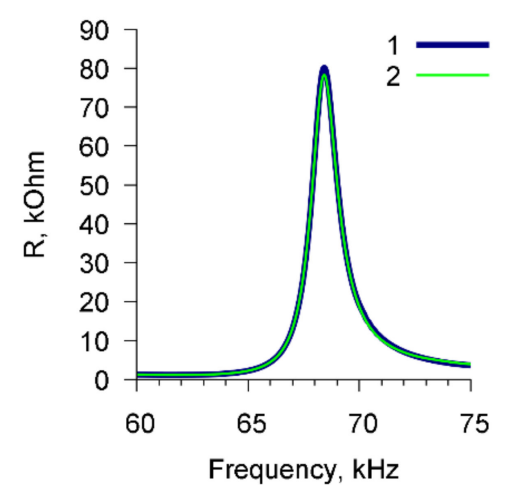

(a)

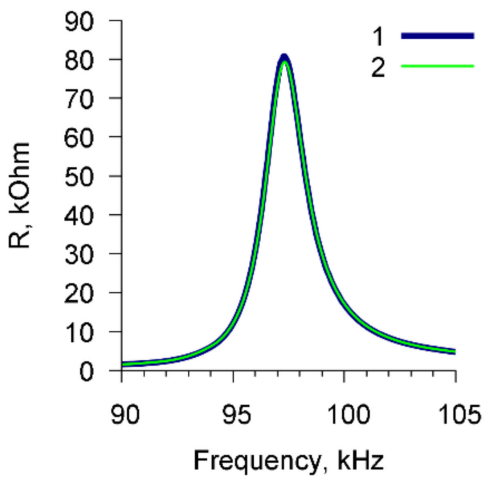

(b)

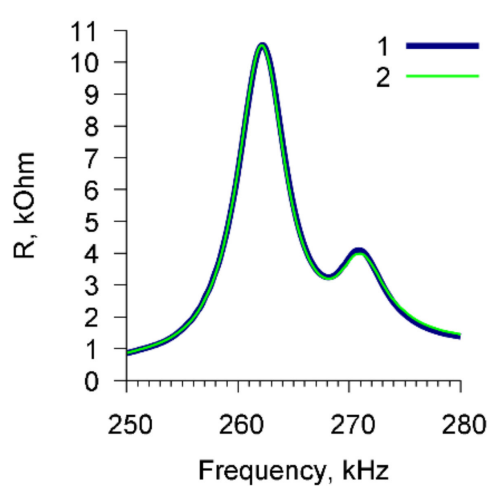

(c)

Figure 4. The frequency dependencies of the real part of the electrical impedance of PZT resonator with container loaded by E. coli K-12 suspension before (curve 1) and after (curve 2) adding the Abs specific to A. brasilense Sp7. The cell concentration was $10^{3}$ cells $/ \mathrm{mL}$, the concentration of Abs was 4 fg/mL. (a) Peak near 68.7 kHz, (b) peak near $97.8 \mathrm{kHz}$, (c) peak near $264 \mathrm{kHz}$.

To determine the specificity of Abs to the O-antigen of A. brasilense Sp7, an immunodiffusion analysis and enzyme-linked immunosorbent assay (ELISA) were performed. During double immunodiffusion, the specific antigen and antibody placed into wells of the agar gel diffuse towards each other and form precipitation in the form of a band at the zone of their meeting. According to the results of immunodiffusion, one can clearly see (Figure 5a) that Abs interacted only with the extract of A. brasilense Sp7 cells (formation of the antigen-antibody complex immunoprecipitation as the band in agarose gel) and did not interact with the extract of E. coli K-12 (no immunoprecipitation band). Thus, the Abs against $\mathrm{O}$-antigen of $A$. brasilense $\mathrm{Sp} 7$ specifically formed the insoluble antigen-antibody complex only with the surface antigens of $A$. brasilense Sp7 [26] and did not form it with antigens of E. coli K-12. ELISA is characterized by the unique specificity of the immunochemical reaction, i.e., antibodies bind exclusively to certain antigens and are highly sensitive to antigen detection. The direct specificity of the Abs used in the work was also determined by ELISA.

The data presented in Figure 5b shows that Abs detected A. brasilense Sp7 cells, but did not detect E. coli K-12. These results indicate the absence of specific antigenic determinants on the cell surface of E. coli K-12.

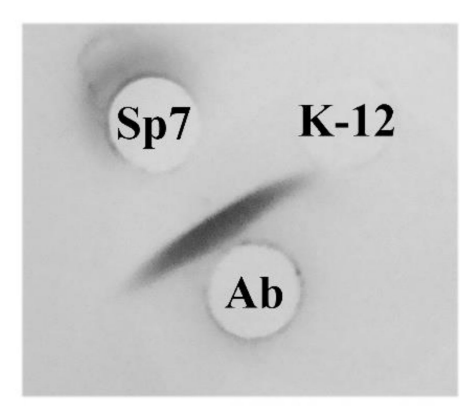

(a)

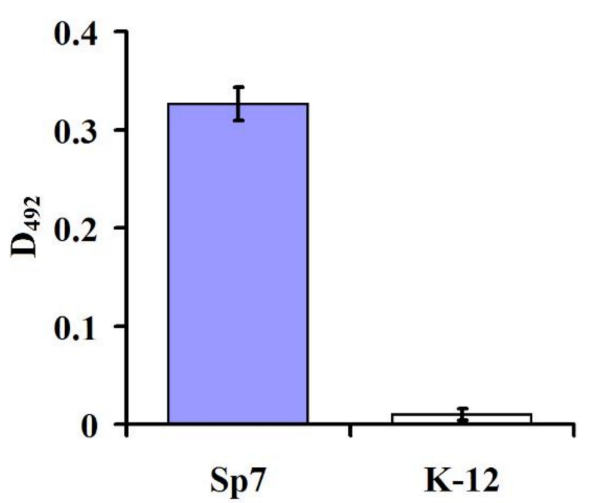

(b)

Figure 5. Results of the immunodiffusion assay (a) and ELISA (b) of strains A. brasilense Sp7 and E. coli $\mathrm{K}-12$ with the antibodies against $A$. brasilense Sp7 O-antigen (Ab). For ELISA, the optical density of the enzyme reaction for a concentration of $10^{6}$ cells $/ \mathrm{mL}$ is shown. 
Additionally, the electron microscopy of microbial cells was performed during their interaction with specific and nonspecific antibodies. Figure 6a presents the electron microscopic identification of A. brasilense Sp7 with Abs specific to A. brasilense Sp7 labeled with colloidal gold. Electron micrographs show that the markers of accumulation occur on the entire surface of the cells. Figure $6 \mathrm{~b}$ shows a photograph of E. coli K-12 with Abs specific to A. brasilense Sp7. One can see that in this case no accumulation of antibodies around the cell is observed.

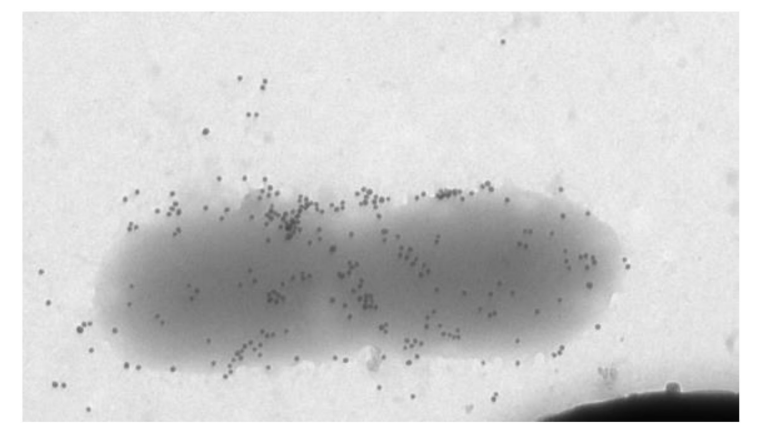

(a)

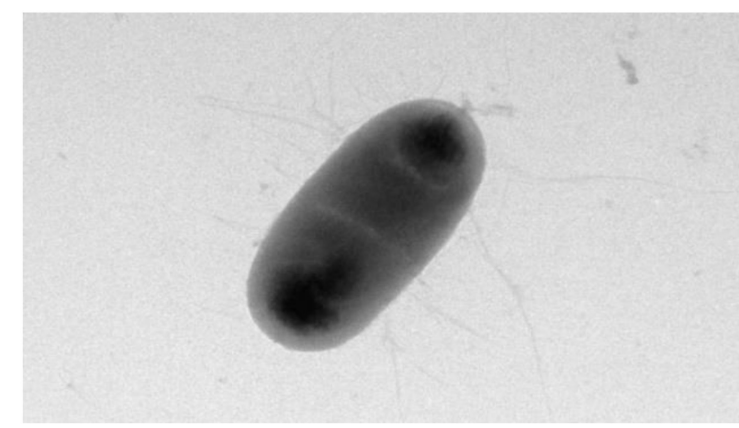

(b)

Figure 6. Electron microscopy of (a) cells of A. brasilense Sp7 with Abs specific to A. brasilense Sp7 labeled with colloidal gold $(\times 10,000)$ and $(\mathbf{b})$ E. coli $\mathrm{K}-12$ with Abs specific to A. brasilense Sp7.

Figure 7 shows the time dependences of the maximum value of the real part of the resonator electrical impedance $\left(\mathrm{R}_{\max }\right)$ for resonant peaks near $68.7,97.8$, and $264 \mathrm{kHz}$ for a specific interaction "A. brasilense Sp7-specific Abs"(a) and non-specific interaction "E. coli K-12-Abs specific for A. brasilense Sp7"(b).

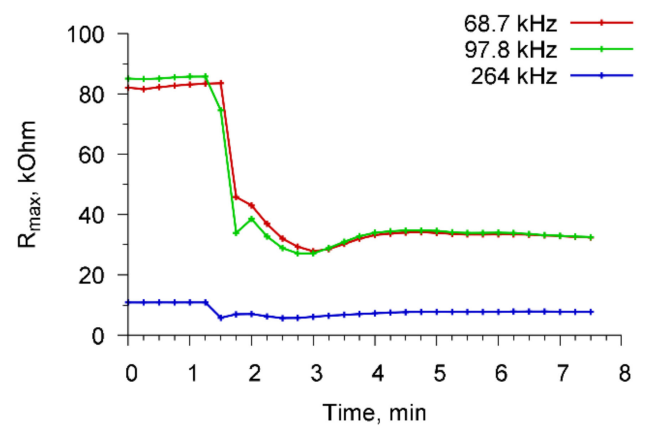

(a)

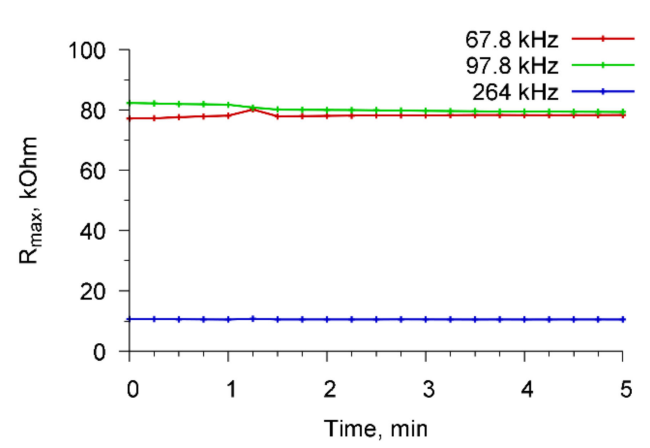

(b)

Figure 7. The time dependencies of the maximum of real part of the electrical impedance of PZT resonator during a specific interaction "A. brasilense Sp7—specific Abs" (a) and nonspecific interaction “E. coli K-12-Abs specific to A. brasilense Sp7 (b), for resonance peaks near frequencies 68.7, 97.8, and $264 \mathrm{kHz}$.

At the initial time, a cell suspension was introduced into the container, and sensor readings were taken at intervals of $15 \mathrm{~s}$. One could see no changes in the value of $R_{\max }$. Then (at 100 th second), a specific/nonspecific reagent was introduced into the container with the cell suspension and the sensor readings were again recorded. It is seen that in the case of a specific interaction (Figure 7a), the value of $R_{\max }$ decreases sharply, and then the saturation process takes place. In the case of nonspecific interaction (Figure $7 \mathrm{~b}$ ), no changes in the sensor parameters occurred. The analysis time in all cases did not exceed 4 min.

We also performed the control experiments when Abs, specific to A. brasilense Sp7, were added to a container with water in the absence of microbial cells. Figure 8 shows the time dependencies of the 
real part of the electrical impedance of the resonator for the resonance peaks near frequencies 68.7, 97.8, and $264 \mathrm{kHz}$ when Abs $(4 \mu \mathrm{g} / \mathrm{mL})$ specific for A. brasilense Sp7 cells were added to the container with water. It is seen that the addition of antibodies to water at the absence of cells did not lead to a change in the electrical impedance of the sensor.

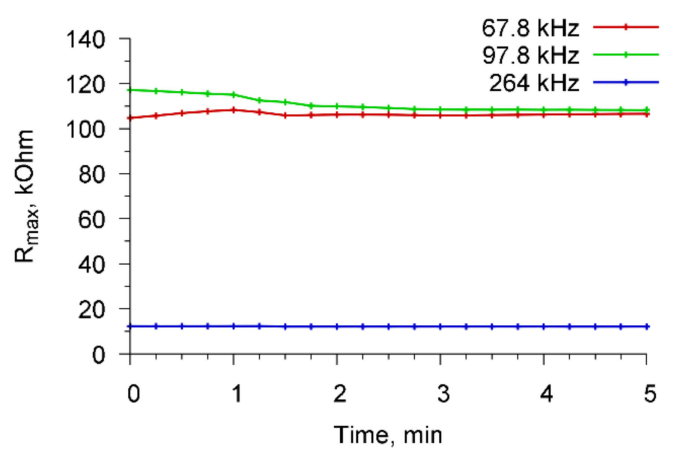

Figure 8. The time dependencies of the maximum of the real part of the electrical impedance of PZT resonator at addition of Abs specific to A. brasilense Sp7 to distilled water without cells for resonance peaks near the frequencies $68.7,97.8$, and $264 \mathrm{kHz}$.

Based on the measured frequency dependencies of the real part of the electrical impedance of the sensor, the dependencies of the change in the maximum value of the real part of the electrical impedance $\left(\Delta R_{\max }\right)$ on the cell concentration was constructed for a fixed value of the number of specific antibodies added to the cell suspension. Figure 9 shows, as an example, the dependencies of $\Delta R_{\max }$ on the concentration of $A$. brasilense Sp7 cells when specific antibodies were added to the container with a cell suspension in an amount of $4 \mu \mathrm{g} / \mathrm{mL}$. Dependences are presented for resonance peaks near frequencies $68.7,97.8$, and $264 \mathrm{kHz}$. It can be seen that the addition of specific Abs to a suspension of cells with a concentration of $10^{2}$ cells $/ \mathrm{mL}$ practically does not change the $R_{\max }$ value $\left(\Delta R_{\max }=0\right)$. This can be explained by the fact that in this case the concentration of cells in the water is very low and the sensor cannot detect a change in the conductivity of the cell suspension due to the specific biological interaction of microbial cells with antibodies.

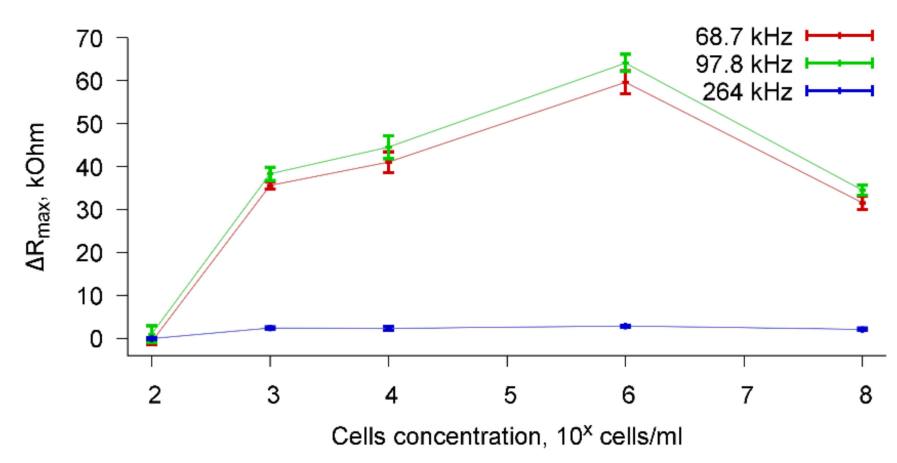

Figure 9. Dependencies of $\Delta \mathrm{R}_{\max }$ of the resonator on the concentration of the A. brasilense Sp7 cells for resonance peaks near the frequencies $68.7,97.8$, and $264 \mathrm{kHz}$ where $\mathrm{x}$ is power. The concentration of antibodies was $4 \mu \mathrm{g} / \mathrm{mL}$.

Significant changes in $\Delta R_{\max }$ are observed when specific antibodies are added to a cell suspension with concentrations of $10^{3}-10^{8}$ cells $/ \mathrm{mL}$. The variation range $\Delta \mathrm{R}_{\max }$ in these cases is $30-60 \mathrm{kOhm}$ for resonance peaks near frequencies of 68.7 and $97.8 \mathrm{kHz}$, and $4-6 \mathrm{kOhm}$ for a peak near the frequency of $264 \mathrm{kHz}$. Figure 9 shows that for cell suspensions with a concentration of $10^{8}$ cells $/ \mathrm{mL}$, a decrease in 
$\Delta \mathrm{R}_{\max }$ is observed compared with a concentration of $10^{3}-10^{6}$ cells $/ \mathrm{mL}$ for resonance peaks near the frequencies of 68.7 and $97.8 \mathrm{kHz}$. This is because the addition of a cell suspension with a concentration of $10^{8}$ cells $/ \mathrm{mL}$ to a liquid container leads to some decrease in sensor signal even before the addition of specific Abs.

To explain this fact, we measured the viscosity and conductivity of cell suspensions with different concentrations and compared them with the viscosity and conductivity of distilled water before adding the cells. It was found that the viscosity of the cell suspension with any concentration of cells was equal to the viscosity of distilled water and amounted to $0.77-0.78 \mathrm{mPa}$. With regard to the conductivity, the addition of cells with a concentration of $10^{2}-10^{6}$ cells $/ \mathrm{mL}$ to distilled water did not lead to a change in the conductivity of the cell suspension compared with the conductivity of distilled water. However, the addition of the cells with a concentration of $10^{8}$ cells $/ \mathrm{mL}$ to distilled water led to an increase in conductivity from $4.5 \mu \mathrm{S} / \mathrm{cm}$ to $6.0 \mu \mathrm{S} / \mathrm{cm}$. This can be explained by the fact that a high-frequency current $(68-264 \mathrm{kHz})$ can pass not only through the space between the cells, but also through the cells.

Thus, we can say that the lower limit of determination of microbial cells using the studied sensor based on PZT ceramics is $10^{3}$ cells $/ \mathrm{mL}$. This value is an order of magnitude higher than the detection limit of the sensor based on lithium niobite [14,15].

The dependencies of a change in the maximum value of the real part of the electrical impedance $\left(\Delta \mathrm{R}_{\max }\right.$ ) on the number of specific Abs (from 1 to $6 \mu \mathrm{g} / \mathrm{mL}$ ) added to the cell suspension with a given value of their concentration were also constructed. Figure 10 shows, as an example, the dependencies of $\Delta \mathrm{R}_{\max }$ on the concentration of specific Abs added to a suspension of $A$. brasilense Sp7 cells with the concentrations $10^{3}$ cells $/ \mathrm{mL}$ (Figure 10a) and $10^{8}$ cells $/ \mathrm{mL}$ (Figure 10b) for three resonance peaks near frequencies $68.7,97.8$, and $264 \mathrm{kHz}$.

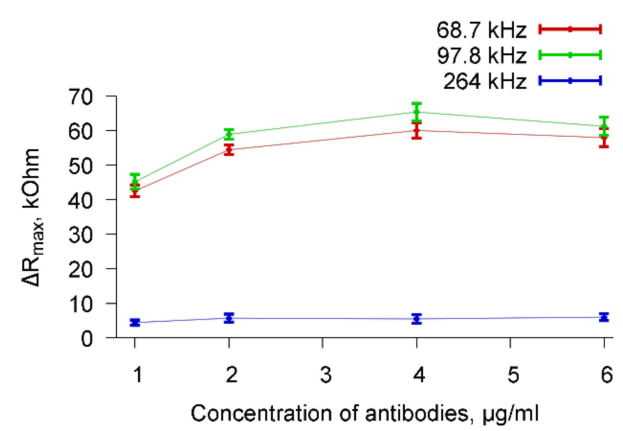

(a)

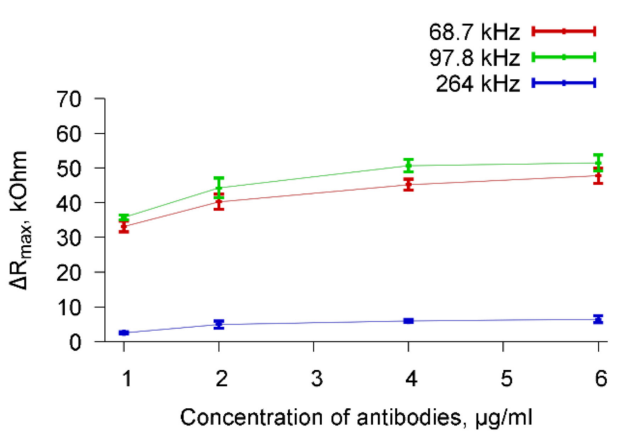

(b)

Figure 10. Dependencies of the change of $\Delta R_{\max }$ of the resonator on the Abs concentration for A. brasilense Sp7 cell suspension after adding the specific Abs for resonance peaks near frequencies 68.7, 97.8 , and $264 \mathrm{kHz}$. The cell concentration is $10^{3}(\mathbf{a})$ and $10^{8}(\mathbf{b})$ cells $/ \mathrm{mL}$.

Figure 10a shows, that adding $1 \mu \mathrm{g} / \mathrm{mL}$ of antibodies to a cell suspension with a concentration of $10^{3}$ cells/mL leads to a change in $R_{\max }\left(\Delta R_{\max }\right)$ of 42,45 , and $4.5 \mathrm{kOhm}$ for resonances near the frequencies of $68.7,97.8$, and $264 \mathrm{kHz}$, respectively. The similar $\Delta \mathrm{R}_{\max }$ values are equal to 57,65 , and $6 \mathrm{kOhm}$ for the quantity of antibodies of $5 \mu \mathrm{g} / \mathrm{mL}$. Figure $10 \mathrm{~b}$ presents the same data for a cell suspension with a concentration of $10^{8}$ cells $/ \mathrm{mL}$. In this case, the $\Delta \mathrm{R}_{\max }$ values were 32,35 , and $3 \mathrm{kOhm}$ (the quantity of antibodies $=1 \mu \mathrm{g} / \mathrm{mL}$ ) and 45,50 , and $5 \mathrm{kOhm}$ (the quantity of antibodies $=5 \mu \mathrm{g} / \mathrm{mL}$ ) for resonances near $68.7,97.8$, and $264 \mathrm{kHz}$, respectively. One can see a decrease in the sensor response for the concentration of $10^{8}$ cells $/ \mathrm{mL}$ as compared to the concentration of $10^{3}$ cells $/ \mathrm{mL}$. An explanation of this fact is given after the commentary on Figure 9.

Thus, it was shown that the addition of specific Abs to the cell suspension leads to a significant change in $\mathrm{R}_{\max }$ even with their minimal amount. Similar dependencies were constructed for other concentrations of microbial cells. 


\subsection{The Measurements in Buffers with Different Conductivity}

As already noted, an important point is the ability to analyze cells in real liquids having high electrical conductivity (tap and industrial water, water in reservoirs, etc.). Therefore, in this section, we studied microbial cells in buffer solutions with different conductivities when interacting with antibodies using an acoustic sensor based on a resonator with a lateral electric field made of PZT ceramics. To carry out this measurement cycle, a measurement methodology was used similar to the procedure described in Section 2. At the first stage, buffer solution with a given conductivity was added to the liquid container and the sensor readings were measured. Then, the container was cleaned and dried, and a microbial buffer solution was added. After the stabilization of the sensor signal, we added Abs specific or nonspecific to the cells and again recorded the sensor readings. In this measurement cycle, A. brasilense Sp7 cells and E. coli cells with a concentration of $10^{3}$ cells $/ \mathrm{mL}$ were used. The concentration of Abs was invariable and amounted to $6 \mu \mathrm{g} / \mathrm{mL}$. The buffer solutions with a conductivity of $10,20,50,100,300,500$, and $1000 \mu \mathrm{S} / \mathrm{cm}$ were used.

As a result of the experiments, the frequency dependencies of the real part of the electrical impedance of the resonator were obtained for all values of the conductivity of the buffer solutions. It was shown that with an increase in the conductivity of the solution, the value of the real part of the electric impedance of the resonator decreased. These data are in good agreement with the data obtained earlier in [25], where the influence of liquid conductivity on the characteristics of a resonator based on PZT ceramics was studied. Adding microbial cells to the buffer solution, as in experiments with distilled water, did not affect the performance of the sensor. Subsequent addition of specific antibodies to the cell suspension led to a significant decrease in the real part of the electrical impedance of the sensor.

Figure 11 shows, as an example, the frequency dependencies of the real part of the electric impedance of the sensor filled by buffer solution with the conductivities of $10 \mu \mathrm{S} / \mathrm{cm}$ (Figure 11a,c,e) and $50 \mu \mathrm{S} / \mathrm{cm}$ (Figure 11b,d,f) with the cells A. brasilense Sp7 before (curve 1) and after (curve 2) adding the specific Abs with concentration of $6 \mu \mathrm{g} / \mathrm{mL}$. The cell concentration is $10^{3}$ cells $/ \mathrm{mL}$.

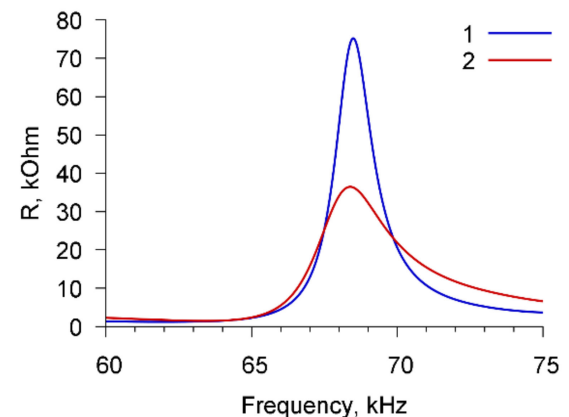

(a)

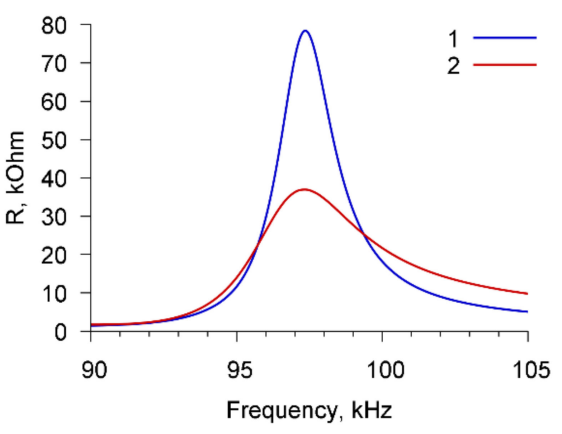

(c)

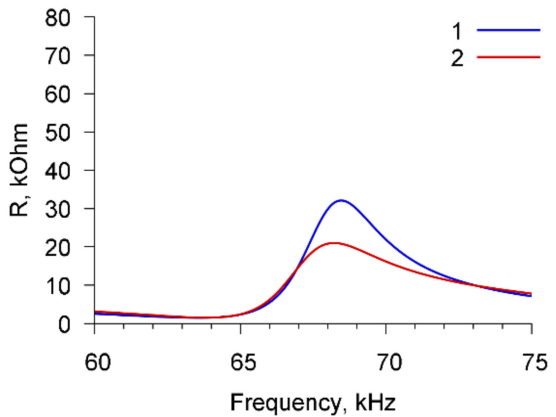

(b)

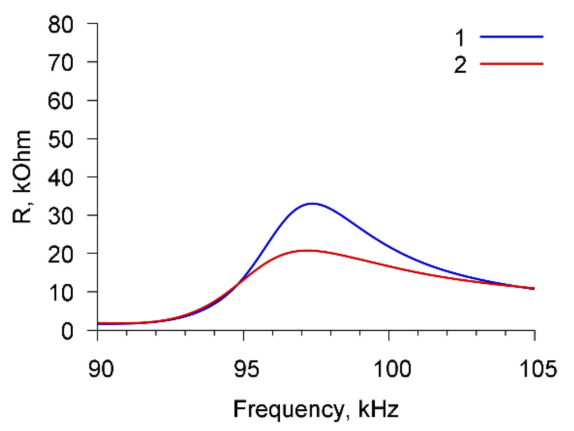

(d)

Figure 11. Cont. 


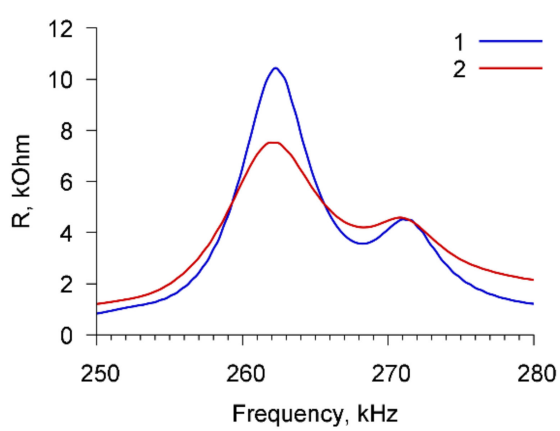

(e)

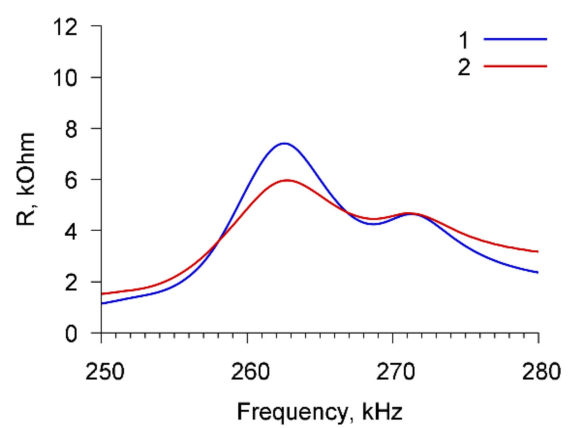

(f)

Figure 11. The frequency dependencies of the real part of the electrical impedance of a PZT resonator with a container loaded with $A$. brasilense Sp7 suspension before (curve 1) and after (curve 2) adding the specific Abs. The cell concentration was $10^{3}$ cells $/ \mathrm{mL}$, the concentration of antibodies was $6 \mu \mathrm{g} / \mathrm{mL}$. The buffer conductivity was $10 \mu \mathrm{S} / \mathrm{cm}(\mathbf{a}, \mathbf{c}, \mathbf{e})$ and $50 \mu \mathrm{S} / \mathrm{cm}(\mathbf{b}, \mathbf{d}, \mathbf{f})$. The resonance peaks correspond to frequencies: $68.7 \mathrm{kHz}(\mathbf{a}, \mathbf{b}), 97.8 \mathrm{kHz}(\mathbf{c}, \mathbf{d})$, and $264 \mathrm{kHz}(\mathbf{e}, \mathbf{f})$.

One can see that the addition of specific Abs to a buffer solution with a conductivity of $10 \mu \mathrm{S} / \mathrm{cm}$ and microbial cells A. brasilense Sp7 (Figure 11a,c,e) leads to a decrease in the maximum value of the real part of the electrical impedance $\mathrm{R}_{\max }$ by $32.1,36.4$, and $2.8 \mathrm{kOhm}$ for resonant peaks near frequencies $67.8,98.7$, and $264 \mathrm{kHz}$, respectively. For a buffer solution with a conductivity of $50 \mu \mathrm{S} / \mathrm{cm}$ containing cells $A$. brasilense Sp7, the maximum value of $\mathrm{R}_{\max }$ decreases by $11.3,12.4$, and $1.5 \mathrm{kOhm}$ due to the addition of specific Abs for the above-mentioned resonance peaks (Figure 11b,d,f).

Based on the frequency dependencies of the real part of the electrical impedance of the sensor presented in Figure 11, the change in $\Delta R_{\max }$ due to the addition of the specific Abs as function of the conductivity of the buffer solution with cells A. brasilense Sp7 were constructed. Figure 12 shows these dependencies for resonance peaks near frequencies 67.8, 98.7, and $264 \mathrm{kHz}$.

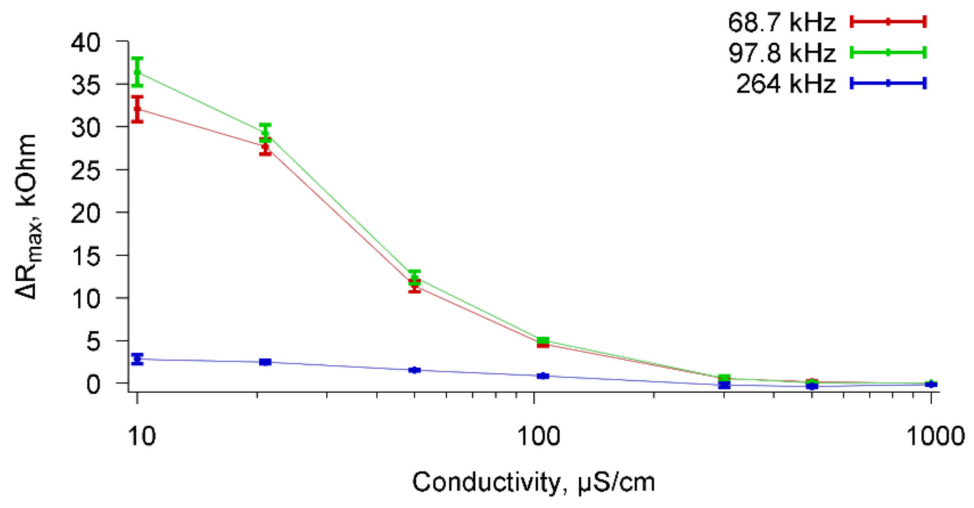

Figure 12. Dependencies of $\Delta \mathrm{R}_{\max }$ on the conductivity of the buffer solution when specific Abs was added to the buffer with the cells A. brasilense Sp7 for resonance peaks near frequencies 67.8, 98.7, and $264 \mathrm{kHz}$.

It can be seen that the value of $\Delta \mathrm{R}_{\max }$ decreases with increasing conductivity of the buffer solutions and reaches zero for the conductivity of $1000 \mu \mathrm{S} / \mathrm{cm}$ for all observed resonance peaks.

Table 1 shows the values of $\Delta \mathrm{R}_{\max }$ for suspensions of $A$. brasilense $\mathrm{Sp} 7$ cells with a concentration of $10^{3}$ cells $/ \mathrm{mL}$ based on distilled water $(4.5 \mu \mathrm{S} / \mathrm{cm})$ and buffer solutions $(10-1000 \mu \mathrm{S} / \mathrm{cm})$ due to the addition of specific Abs in an amount of $6 \mu \mathrm{g} / \mathrm{mL}$ for resonant peaks near frequencies of 67.8, 98.7, and $264 \mathrm{kHz}$. 
Table 1. The values of $\Delta R_{\max }$ for suspensions of $A$. brasilense Sp7 cells with a concentration of $10^{3}$ cells/mL based on distilled water $(4.5 \mu \mathrm{S} / \mathrm{cm})$ and buffer solutions $(10-1000 \mu \mathrm{S} / \mathrm{cm})$ due to the addition of specific Abs in an amount of $6 \mu \mathrm{g} / \mathrm{mL}$ for resonant peaks near frequencies of $67.8,98.7$, and $264 \mathrm{kHz}$.

\begin{tabular}{cccc}
\hline Conductivity, $\boldsymbol{\mu S} / \mathbf{c m}$ & $\begin{array}{c}\Delta \mathbf{R}_{\text {max }}, \mathbf{k O h m}, \\
\text { peak } \mathbf{6 8 . 7} \mathbf{~ k H z}\end{array}$ & $\begin{array}{c}\Delta \mathbf{R}_{\text {max }}, \mathbf{k O h m}, \\
\text { peak 97.8 } \mathbf{~ k H z}\end{array}$ & $\begin{array}{c}\Delta \mathbf{R}_{\text {max }}, \mathbf{k O h m}, \\
\text { peak 264 } \mathbf{~ k H z}\end{array}$ \\
\hline 4.5 & 63.5303 & 65.5608 & 4.09908 \\
10 & 32.0923 & 36.3881 & 2.81509 \\
20 & 27.6936 & 29.2813 & 2.48143 \\
50 & 11.3743 & 12.3867 & 1.53813 \\
100 & 4.59971 & 5.02662 & 0.86089 \\
300 & 0.64757 & 0.68282 & 0.32149 \\
500 & 0.17027 & 0.25516 & 0.13604 \\
1000 & 0.09172 & 0.03193 & 0.04684 \\
500 (pure water) & 0.18135 & 0.26791 & 0.12341 \\
1000 (tap water) & 0.09163 & 0.03152 & 0.03571 \\
\hline
\end{tabular}

From the data given in the Table 1 it can be seen that the sensor can successfully detect specific reactions of microbial cells with Abs in solutions with conductivity up to $300 \mu \mathrm{S} / \mathrm{cm}$. For the solutions with the higher conductivity, the measurement data are comparable with the measurement error. Additionally, the measurements were carried out with the samples of tap water (conductivity $=1000 \mu \mathrm{S} / \mathrm{cm}$ ), as well as with the samples of purified drinking water (conductivity $=500 \mu \mathrm{S} / \mathrm{cm}$ ). The data obtained are presented in the lower two rows of Table 1 . They are well comparable with the data for buffer solutions.

As the control experiments, the interactions of a cell suspension with non-specific reagents were investigated. For this purpose, we used E. coli K-12 cells and Abs specific for A. brasilense Sp7 cells and non-specific for $E$. coli K-12 cells. Figure 13 shows the dependencies of $\Delta \mathrm{R}_{\max }$ on the conductivity of the buffer solution when Abs specific for A. brasilense Sp7 cells was added to the buffer with E. coli K-12 cells for resonance peaks near frequencies 67.8, 98.7, and $264 \mathrm{kHz}$.

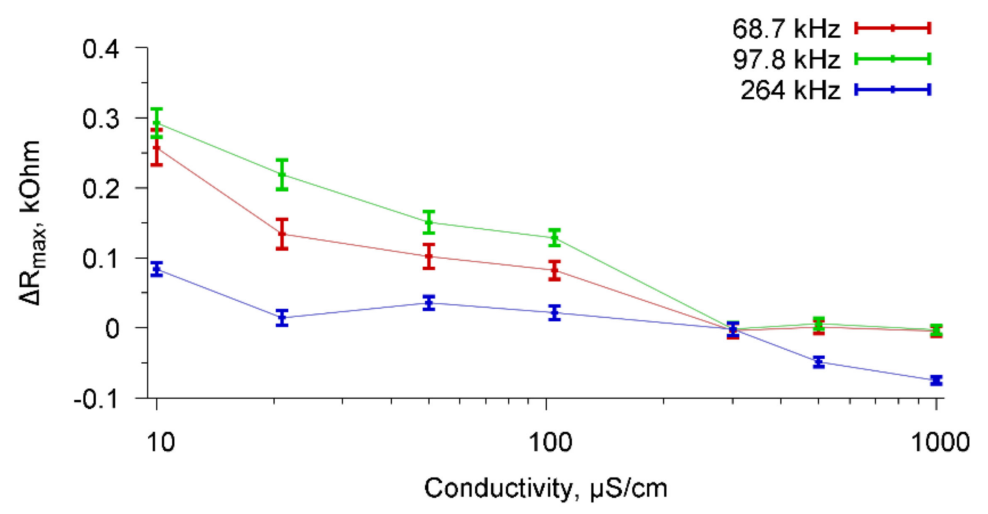

Figure 13. Dependencies of $\Delta \mathrm{R}_{\max }$ on the conductivity of the buffer solution when Abs specific for A. brasilense $\mathrm{Sp} 7$ cells was added to the buffer with $E$. coli $\mathrm{K}-12$ cells for resonance peaks near frequencies $67.8,98.7$, and $264 \mathrm{kHz}$.

One can see that the nonspecific interactions practically did not lead to a change in the parameters of the sensor for each value of the conductivity of buffer solution. Thus, a sensor based on a resonator with a lateral electric field made of PZT ceramics confidently distinguishes specific biological interactions from non-specific interactions. This means that the sensor can be used not only for the detection of microbial cells in the aquatic environment, but also for their identification.

It should be noted that in most works devoted to acoustic biological sensors [7,10,12], active layers with immobilized antibodies are used. Such an approach is distinguished, first, by the long analysis 
time (more than $6 \mathrm{~h}$ [12]) and, second, by the need to remove the spent active film after each analysis. A biological sensor based on a piezoelectric resonator with a lateral electric field allows bacteria to be analyzed directly in the liquid phase without an active layer for several minutes. The team of authors of this paper has previously shown the possibility of using a resonator with a lateral electric field based on lithium niobate to record various biological interactions of bacterial cells with antibodies, bacteriophages, and mini-antibodies [13-15] with the sensitivity threshold of $10^{4}$ cells/mL. However, the quality factor of the pointed resonator on the plate of lithium niobate in contact with the liquid was found to be too low [26], since the excited longitudinal wave in such a resonator led to radiation loss in the liquid. The sensor based on a resonator made of PZT ceramics presented in this paper allowed a reduction in the value of the threshold up to $10^{3}$ cells $/ \mathrm{mL}$. This may be explained by the fact that for the dominant mode of the PZT resonator the shear component of the mechanical displacement is predominant and this greatly reduces radiation loss upon contact with the liquid. It has been also shown that the sensor confidently detects specific biological interactions of microbial cells in aqueous solutions with conductivity up to $300 \mu \mathrm{S} / \mathrm{cm}$. Such conductivity is characteristic, for example, of well-treated tap water.

The results obtained showed that the magnitude of the change in the output parameters of the investigated sensor depends on the concentration of bacterial cells in the cell suspension. This opens up the prospects for further work in terms of quantitative analysis of microbial cells. Furthermore, we plan to continue research on this sensor in order to study its capabilities for rapid analysis of viral particles.

\section{Conclusions}

The conducted studies showed that the interaction of microbial cells with specific antibodies leads to a significant change in the electrical impedance of the sensor based on a resonator with a lateral electric field made of PZT ceramics. The sensor has high sensitivity and speed. It was shown that the sensor confidently detects microbial cells with a low concentration $\left(10^{3}\right.$ cells $\left./ \mathrm{mL}\right)$ not only in distilled water, but also in buffer solutions with conductivity as high as $300 \mu \mathrm{S} / \mathrm{cm}$. This opens up the possibility of using a sensor for the analysis of microorganisms in real liquids, such as tap and industrial water, and food liquids. The absence of a sensor reaction to a non-specific biological interaction allows the use of this sensor not only to detect bacterial cells, but also to identify them in an aquatic environment. A short analysis time, which did not exceed $4 \mathrm{~min}$ in this study, allows the use of this sensor for rapid diagnosis of microbial cells.

Author Contributions: Conceptualization, I.B., B.Z. and O.G.; Data curation, I.B., A.T. and O.G.; Formal analysis, O.G.; Investigation, I.B., A.T., and O.G.; Methodology, I.B. and O.G.; Project administration, I.B.; Resources, G.B., O.G.; Software, A.T.; Validation, I.B. and B.Z.; Visualization, A.T.; Writing—original draft, I.B.; Writing-review \& editing, B.Z. and O.G. All authors have read and agreed to the published version of the manuscript.

Funding: This research was partially supported by the Russian Foundation for Basic Research grants No. 19-07-00304, 20-07-00602.

Acknowledgments: We are grateful to the Simbioz Center for the Collective Use of Research Equipment in the Field of Physical-Chemical Biology and Nanobiotechnology, IBPPM RAS for materials provided for conducting experiments.

Conflicts of Interest: The authors declare no conflict of interest.

\section{References}

1. Chen, S.; Cheng, Y.F. Biosensors for bacterial detection. Int. J. Biosens. Bioelectron. 2017, 2, 197-199. [CrossRef]

2. Ejeiana, F.; Etedalia, P.; Mansouri-Tehrania, H.-A.; Soozanipoura, A.; Low Ze-Xian Mohsen, A.; Asghar, T.-K.; Razmjou, A. Biosensors for wastewater monitoring: A review. Biosens. Bioelectron. 2018, 118, 66-79. [CrossRef] [PubMed]

3. Tan, L.; Schirmer, K. Cell culture-based biosensing techniques for detecting toxicity in water. Curr. Opin. Biotechnol. 2017, 45, 59-68. [CrossRef] [PubMed] 
4. Raich, J. Review of Sensors to Monitor Water Quality; Publications Office of the European Union: Luxembourg, 2013; Volume 33. [CrossRef]

5. Gao, J.; Sin, M.L.; Liu, T.; Gau, V.; Liao, J.C.; Wong, P. Hybrid electrokinetic manipulation in high-conductivity media. Lab Chip 2011, 11, 1770-1775. [CrossRef] [PubMed]

6. Kanoatov, M.; Krylov, S.N. Analysis of DNA in Phosphate Buffered Saline Using Kinetic Capillary Electrophoresis. Anal. Chem. 2016, 88, 7421-7428. [CrossRef] [PubMed]

7. Andle, J.C.; Vetelino, J.F. Acoustic wave biosensors. Sens. Actuators A Phys. 1994, 44, 167-176. [CrossRef]

8. Andrä, J.; Böhling, A.; Gronewold, T.M.A.; Schlecht, U.; Perpeet, M.; Gutsmann, T. Surface acoustic wave biosensor as a tool to study the interactions of antimicrobial peptides with phospholipid and lipopolysaccharide model membranes. Langmuir 2008, 24, 9148-9153. [CrossRef] [PubMed]

9. Don, E.; Farafonova, O.; Pokhil, S.; Barykina, D.; Nikiforova, M.; Shulga, D.; Borshcheva, A.; Tarasov, S.; Ermolaeva, T.; Epstein, O. Use of piezoelectric immunosensors for detection of interferon-gamma interaction with specific antibodies in the presence of released-active forms of antibodies to interferon-gamma. Sensors 2016, 16, 96. [CrossRef] [PubMed]

10. Wark, M.; Kalanyan, B.; Ellis, L. A Lateral Field Excited Acoustic Wave Sensor for the Detection of Saxitoxin in Water. In Proceedings of the 2007 IEEE Ultrasonics Symposium, New York, NY, USA, 28-31 October 2007; pp. 1217-1220. [CrossRef]

11. Handa, H.; Gurczynski, S.; Jackson, M.P.; Auner, G.; Mao, G. Recognition of Salmonella typhimurium by immobilized phage P22 monolayers. Syrf. Sci. 2008, 602, 1393-1400. [CrossRef] [PubMed]

12. Vetelino, J.F. A lateral field excited acoustic wave sensor platform. In Proceedings of the 2010 IEEE International Ultrasonics Symposium, San Diego, CA, USA, 11-14 October 2010; pp. 2269-2272. [CrossRef]

13. Zaitsev, B.D.; Kuznetsova, I.E.; Shikhabudinov, A.M.; Ignatov, O.V.; Guliy, O.I. Biological sensor based on the lateral electric field excited resonator. IEEE Trans. Ultrason. Ferroelectr. Freq. Control 2012, 59, 963-969. [CrossRef] [PubMed]

14. Guliy, O.I.; Zaitsev, B.D.; Kuznetsova, I.E.; Shikhabudinov, A.M.; Matora, L.Y.; Makarikhina, S.S.; Ignatov, O.V. Investigation of specific interactions between microbial cells and polyclonal antibodies using a resonator with lateral electric field. Microbiology 2013, 82, 215-223. [CrossRef]

15. Guliy, O.I.; Zaitsev, B.D.; Shikhabudinov, A.M.; Borodina, I.A.; Karavaeva, O.A.; Larionova, O.S.; Volkov, A.A.; Teplykh, A.A. A method of acoustic analysis for detection of bacteriophage-infected microbial cells. Biophysics 2017, 62, 580-587. [CrossRef]

16. McCann, D.F.; McCann, J.M.; Parks, J.M.; Frankel, D.J.; Pereira da Cunha, M.; Vetelino, J.F. A lateral-field-excited $\mathrm{LiTaO}_{3}$ high frequency bulk acoustic wave sensor. IEEE Trans. Ultrason. Ferroelectr. Freq. Control 2009, 56, 779-787. [CrossRef] [PubMed]

17. Zaitsev, B.D.; Shikhabudinov, A.M.; Teplykh, A.A.; Kuznetsova, I.E. Liquid sensor based on a piezoelectric lateral electric field-excited resonator. Ultrasonics 2015, 63, 179-183. [CrossRef] [PubMed]

18. Ma, T.; Wang, J.; Du, J.; Yang, J. Resonances and energy trapping in AT-cut quartz resonators operating with fast shear modes driven by lateral electric fields produced by surface electrodes. Ultrasonics 2015, 50, 14-20. [CrossRef] [PubMed]

19. Teplykh, A.; Zaitsev, B.; Kuznetsova, I. Lateral electric field excited resonator based on PZT ceramics. In Proceedings of the 2015 IEEE International Ultrasonics Symposium (IUS), Taipei, Taiwan, 21-24 October 2015. [CrossRef]

20. Ibrahim, S.; Ramadan, R.; Mohamed, A. Piezoelectric Ceramic Materials; Lap Lambert Academic Publishing GmbH \& Company KG: Saarbrucken, Germany, 2011; Volume 116.

21. Matora, L.; Shvartsburd, B.I.; Shchegolev, S. Immunochemical analysis of O-specific polysaccharides from the soil nitrogen-fixing bacteria Azospirillumbrasilense. Microbiology 1998, 67, 677-681.

22. Ouchterlony, O.; Nilsson, L.-A. Immunodiffusion and immunoelectrophoresis. In Handbook of Experimental Immunology; Weir, D.M., Ed.; Blackwell Scientific: Oxford, UK, 1978; pp. 19.1-19.44.

23. Yegorenkova, I.V.; Tregubova, K.V.; Matora, L.Y.; Burygin, G.L.; Ignatov, V.V. Use of ELISA with antiexopolysaccharide antibodies to evaluate wheat-root colonization by the rhizobacterium Paenibacilluspolymyxa. Curr. Microbiol. 2010, 61, 376-380. [CrossRef] [PubMed]

24. Guliy, O.I.; Matora, L.Y.; Burygin, G.L.; Dykman, L.A.; Ostudin, N.A.; Bunin, V.D.; Ignatov, V.V.; Ignatov, O.V. Electrophysical characteristics of Azospirillumbrasilense Sp245 during interaction with antibodies to various cell surface epitopes. Anal. Biochem. 2007, 370, 201-205. [CrossRef] [PubMed] 
25. Borodina, I.A.; Zaitsev, B.D.; Teplykh, A.A. Influence of the conductivity of a liquid contacting with a lateral electric field excited resonator based on PZT ceramics on its characteristics. Ultrasonics 2020, 102, 106059. [CrossRef] [PubMed]

26. Khlebtsov, B.N.; Burygin, G.L.; Matora, L.Y.; Shchyogolev, S.Y.; Khlebtsov, N.G. A method for studying insoluble immune complexes. Biochim. Biophys. Acta 2004, 1670, 199-207. [CrossRef] [PubMed]

(C) 2020 by the authors. Licensee MDPI, Basel, Switzerland. This article is an open access article distributed under the terms and conditions of the Creative Commons Attribution (CC BY) license (http://creativecommons.org/licenses/by/4.0/). 